\title{
EFEKTIVITAS PEMANFAATAN PUPUK BOKASI, CASTING DAN PUPUK GENDONING (LARVA KUMBANG KELAPA/Orcyctes rhinoceros)
}

\author{
Lianah \\ Tadris Biologi Fakultas Tarbiyah IIAIN Walisongo Semarang
}

Corresponding author: lianahkuswanto@yahoo.co.id

\begin{abstract}
ABSTRAK
Kotoran hewan dan sampah organik dapat mencemari di lingkungan air, udara dan tanah. Penelitian ini bertujuan untuk membandingkn keefektifan antara pupuk gendoning dan pupuk bokashi. Proses pengomposan dapat dipercepat dengan bantuan aktifator EM4 (Efektif Mikroorganisme). Proses pengomposan tersebut juga dapat melibatkan hewan lain yaitu Cacing tanah dan larva kumbang kelapa (Orcyctes rhinoceros) yang disebut dengan nama gendon (bahasa Jawa) yang bekerja sama dengan mikroba dalam proses dekomposer. Gendon dalam hal ini memakan bahan organik yang tidak terurai, mencampur bahan organik dan membuat lubang-lubang aerasi. Kehadiran gendon dapat mempercepat penghancuran bahan organik karena mempunyai mulut yang tajam sebagai mesin pencacah sampah organik. Metode penelitian eksperimen sampah organik ditreatmen yaitu dengan menggunakan EM4, dan dengan menggunakan gendon. Peruraian oleh EM4 disebut pupuk Bokashi. Sedang keterlibatan gendon dalam proses pengomposan menghasilkan butir-butir kecil
\end{abstract}


berwarna hitam dinamakan pupuk Gendoning (penemuan pribadi). Dari kedua pupuk tersebut dipraktekan untuk menanam labu air (Lagenaria leucantha). Dari experimen tersebut dapat diketahui bahwa pupuk gendoning ini terbukti lebih efektif dan efisien dari pupuk bokashi, karena gendon mampu melakukan dekomposisi lebih sempurna dari EM4. Dekomposisi tersebut dilakukan baik secara mekanik maupun secara enzimatis. Pupuk gendoning adalah hasil bioteknologi sederhana yang dapat menjadi alternatif dalam mengatasi kelangkaan pupuk, sebagai pupuk organik yang efektif dan efisien serta bernilai ekonomis sebagai.

Kata kunci : Efektivitas, Pupuk Bokashi, pupuk gendoning,larva kumbang 


\section{Pendahuluan}

Kotoran hewan dan sampah organik dapat mencemari lingkungan air, udara dan tanah. Akan tetapi sampah tidak lagi menjadi bahan pencemar apabila diberi sentuhan bioteknologi sederhana akan menjadi sumber daya yang bermanfaat. Awalnya peneliti dan para siswa SMPN 1 Kendal sudah lama memperoduksi pupuk bokashi dari sampah jerami dan daun-daunan kering dari lingkungan sekolah (petunjuk praktek terlampir). Akan tetapi hasilnya kurang maksimal karena daun-daun tidak dipotong-potong terlebih dahulu, sebab kami tidak memiliki mesin pemotong tersebut. Akibatnya pupuk bokashi yang diperkirakan cepat produksinya ternyata masih cukup lama. Pupuk tersebut diperkirakan matang selama $1 \mathrm{~s} / \mathrm{d} 2 \mathrm{minggu}$, namun kenyataannya lebih dari tiga minggu belum matang semuanya. Masih setengah matang dan bahkan ada yang masih mentah. Lalu kami biarkan beberapa lama aitu 8 minggu $( \pm 2$ bulan), sampah tersebut sudah matang semua. Ketika akan dikemas ternyata banyak ulat besar berbulu dan berwarna putih sangat lahap sekali memakan sampah yang semula sampah tersebut tingginya $1 \mathrm{~m}$ menyusut tinggal $1 / 3$ nya. Ulat tersebut bukan ulat biasa akan tetapi larva dari kumbang kelapa yang dikenal dengan nama gendon (bahasa Jawa).

Gendon selama ini dianggap hewan tak berguna dan menjijikan. Induk gendon (Oryctes rhinoceros) menjadi hama pohon kelapa sebab sering merusak dan melubangi pohon tersebut untuk tempat tinggal dan sumber mendapatkan makanan. Akan tetapi ada pula kumbang berkembang biak di tumpukan sampah sampah organik dan kotoran hewan. Gendon memiliki mulut tajam dan kuat yang berfungsi untuk menghancurkan makanan menjadi lembut. Gendon menghasilkan kotoran yang berupa butiran-butiran kecil berwarna hitam. Kotoran tersebut kemudian peneliti beri nama pupuk gendoning. Peristiwa peruraian oleh mikroorganisme disebut komposing sedang dalam peristiwa peruraian oleh gendon peneliti sebut sebagai gendoning.

Gendon merupakan larva atau bentuk sementara dari rantai metamorfosis kumbang. Ia akan menjadi kumbang setelah 1 
bulan. Larva kumbang menghabiskan sebagian waktunya untuk makan dan tumbuh. Ia makan secara terus menerus dan tumbuh dengan cepat. Akan tetapi kulitnya yang keras tidak ikut tumbuh dan ia harus berganti kulit beberapa kali sebelum menjadi kepompong. Bila sudah berganti kulit, kulit yang lama terbelah dibagian belakang pada saat ia menggeliat pada kulit yang lama. mula-mula muncul kepalanya, disusul dengan tubuh yang empuk dan transparan. Kemudian berangsur kulit-kulit baru tumbuh dan mengeras. Secara alamiah larva mengubur diri dalam tanah menggali liang dalam tanah serta mencari makan. Larva tersebut kemudian membuat bilik kepompong pada awalnya kekompong kumbang berwarna terang berubah menjadi gelap. Berangsur-angsur tubuh kumbang dewasa terlihat dibalik kulit pelindungnya. Kaki, sayap, antena, mulut dan mata kumbang dewasa terbentuk. Kumbang menjalani metamorfosis sempurna telur yang baru keluar ukurannya $0,25 \mathrm{~cm}$ setelah 10 hari menetas menjadi Larva dengan ukuran $1,25 \mathrm{~cm}$ dalam seminggu berubah menjadi $2,5 \mathrm{~cm}$. Larva adalah kumbang muda yang bentuknya seperti ulat, tak bermata, sama sekali tidak mirip dengan kumbang dewasa. Mereka menghabiskan sebagian besar untuk tumbuh dan makan. Bila tubuhnya telah tumbuh cukup besar, mereka siap memasuki tahap ke 3 dari siklus hidupnya sebagai kepompong. Mereka menggali lubang tanah atau pada batag pohon. Mereka tidur tak bergerak dalam bilik kepompongnya dan hidup dengan persediaan makanan yang cukup. Pada saat itulah tubuhnya mulai berubah menjadi kumbang dewasa (Oda, 1998). Selanjutnya kumbang jantang dan betina kawin, lalu menghasilkan telur bagi dan seterusnya mengalami siklus metamorfosis secara sempurna. Sadar atau tidak sadar setiap hari kita makan hasil dari pertanian. Apa yang terjadi? Adanya kelangkaan pupuk terjadi dimana-mana.

Para petani terlanjur tergantung pada pupuk kimia yang praktis, hasil pertanian sangat rendah tidak sebanding dengan jerih payah petani. Harga pupuk yang mahal, benih, dan tenaga yang mahal, sehingga petani menjerit, terutama tentang mahalnya pupuk. Apakah para petani tidak dapat membuat pupuk 
sendiri? Bagaimana cara membuatnya ? Darimana peratalan atau mesin-mesinnya ? Tuhan menciptakan sesuatu pasti ada manfaatnya, termasuk gendon yang selama ini dikenal sebagai hewan yang menjijikan dan tidak berguna. Ternyata gendon dapat dimanfaatkan sebagai mesin pencacah sampah organik.

\section{Fokus Masalah :}

1. Bagaimana cara memanfaatkan gendon untuk membuat pupuk gendoning?

2. Apakah pupuk gendoning lebih efektif daripada pupuk bokashi?

3. Tujuan

4. Memanfaatkan gendon sebagai stimulator dalam pembuatan pupuk gendoning.

5. Membuktikan efektifitas pupuk gendoning dan pupuk bokashi.

\section{Manfaat}

1. Memberi alternatif solusi terhadap kelangkaan pupuk.

2. Mensosialisasikan limbah lingkungan menjadi bernilai ekonomis sebagai hasil bioteknologi sederhana.

Menurut Oda (1998) larva kumbang kelapa/gendon dapat mengkonsumsi sejumlah makan setiap hari seberat tubuhnya misal 10 ekor gendon berat rata-rata 30 gram maka dibutuhkan sampah 300 gram perhari. Jika 100 ekor gendon berapa sampah yang dibutuhkan? Belum kalau 1000 gendon dan seterusnya. Ternyata cukup banyak sampah yang dibutuhkan. Ini berarti dapat mengatasi sampah yang merajalela di masyarakat. Akan tetapi sampah yang bisa diurai oleh gendon adalah sampah organik. Untuk itu disarankan sebelum membuang sampah sebaiknya dipisahkan terlebih dahulu antara sampah organik dan anorganik. Sampah organik dibiarkan dalam bak/tong sampah lalu diberi EM4 agar terjadi fermentasi baru diberi gendon. Sedangkan sampah anorganik dapat didaur ulang dengan jalan diberikan kepada pemulung untuk dilanjutkan ke proses pendaur 
Lianah

ulang.

\section{Metode Penelitian}

Penelitian ini menggunakan metode eksperimen murni yaitu membandingkan keefekifan antara pupuk gendoning dan pupuk bokashi yang diujikan pada tanaman labu air (Lagenaria leucantha). Pembuatan kompos ini mengikuti Sistem Open Window dengan membuat pupuk ke dalam beberapa wadah dengan menggunakan beberapa stimulator yaitu dengan stimulator EM4 (E), dengan stimulator gendon (G), dengan stimulator EM4 dan gendon (EG), serta kelompok kontrol (K).

Kegiatan ini dilakukan dengan pembuatan sampah organik dalam wadah, pemberian bahan stimulator, pengadukan, pengomposan, pengeringan, pengamatan, pengayaan. Selama pengomposan juga dilakukan pemantauan suhu dan penyiraman apabila sampah terlalu kering sampai kadar air kurang lebih $55 \%$. Pengomposan diakhiri pada minggu ke 6. Untuk mengetahui waktu pematangan kompos dilakukan pengamatan ratio $\mathrm{C} / \mathrm{N}$ pada minggu ke 4, 5 dan 6 . Untuk mengetahui kualitas kompos dilakukan analisis terhadap kandungan unsur $\mathrm{N}, \mathrm{P}, \mathrm{K}$.

\section{Pengujian Kompos untuk Konservasi Tanah dan Produksi Tanaman pada Lahan Kering}

Rancangan penelitian yang digunakan adalah Rancangan Acak Kelompok (RAK), pola faktorial (4X4) dan 3 ulangan. Faktor yang dimaksud adalah :

Jenis kompos : $\mathrm{G}$ : kompos stimulator Gendon, E : kompos stimulator EM4' K : kompos tanpa stimulator.

Dosis kompos (D) :D0: dosis 0kg / pohon, D1 : dosis 0,1 kg/pohon,D2 : dosis 0,2kg/pohon, D3 : dosis $0,3 \mathrm{~kg} /$ pohonD4 : dosis 0,4 kg/pohon,D5 :0,5kg/pohon.

Percobaan di lahan kering dan kaku dabekas urugan wadas di lingkungan SMPN I Kendal dilakukan dengan membuat 
petak-petak percobaan dengan ukuran masing-masing petak $2 \mathrm{X}$ $2 \mathrm{~m}^{2}$. Pemberian kompos sesuai perlakuan kompos dengan bahan stimulator dan dosis yang berbeda dilakukan dengan menyebar kompos diatas permukaan petak lahan. Penanaman bibit yang berumur 15 hari pada tanah sedalam $3 \mathrm{~cm}$. Pemanenan dilakukan saat tanaman berumur 3 bulan. Variabel yang diamati adalah pertumbuhan daun,batang bung, dan buah. Variabel tanah yang diamati adalah kandungan bahan organik sebelum dan sesudah percobaan, erodibilitas tanah dengan pengamatan \% liat terdispersi (Baldock, 1994) sebelum perlakuan, awal tanam saat tingkat erosi tertinggi terjadi (Lal, 1984) dan setelah panen.

\section{Cara Kerja}

Eksperimen I : Jenis kompos E

Pengomposan $1 \mathrm{~kg}$ sampah organik dengan stimulator EM4 dengan dosis $0,5 \mathrm{ml}, 0,1 \mathrm{ml}$ dan 10ml EM4 ke dalam tiga wadah yang berbeda.

Eksperimen II: Jenis kompos G

Pengomposan $1 \mathrm{~kg}$ sampah organik dengan stimulator gendon ke dalam tiga wadah masing-masing 5 ekor, 10 ekor, dan 15 ekor

Eksperimen III: Jenis kompos

Pengomposan $1 \mathrm{~kg}$ sampah organik tanpa stimulator

\section{Hasil dan Pembahasan}

\section{Hasil}

Dari percobaan 1, 2, dan 3 sesuai dengan petunjuk praktikum diperoleh hasil pada table 1 sebagai berikut: 
Tabel 1. Pengamatan Percobaan I : Pengomposan Sampah langsung diberi gendon

\begin{tabular}{|c|c|c|c|c|}
\hline No. & $\begin{array}{c}\text { Per- } \\
\text { lakuan }\end{array}$ & Rata-rata Waktu & $\begin{array}{c}\text { Berat } \\
\text { rata-rata } \\
\text { Kompos } \\
\text { yang } \\
\text { Terbentuk } \\
\text { (gram) }\end{array}$ & Pupuk \\
\hline 1. & E & 3 minggu & 0,32 & Bokashi \\
\hline 2. & G & $4-7$, hari & 0,33 & Gendoning \\
\hline 3 & K & 6 minggu & 0,38 & Kompos \\
\hline
\end{tabular}

Tabel 1 menunjukan hasil kompos yang paling cepat terbentuk dengan waktu hanya 5 hari yaitu kompos dengan stimulator gendon. Sedangkan untuk stimulator EM4, proses pengomposannya hanya dilakukan secara enzimatis sehingga prosesnya lebih lama. Rendahnya bahan organik pada kontrol disebabkan karena mikroorganisme yang berperan dalam dekomposisi bukan mikroorganisme terpilih sehingga dekomposisi berjalan lambat.

Hasil ekperimen diatas, sampah tersebut berubah menjadi butiran-butiran hitam yang merupakan kotoran gendon. Kotoran tersebut tidak berbau seperti kotoran hewan lainnya. Kotoran tersebut oleh peneliti disebut pupuk gendoning.

Pupuk diujicobakan untuk memupuk tanaman labu air yang ditanam di lingkungan SMP N I Kendal. Dari ujicoba tersebut diketahui tanaman yang diberi pupuk gendoning tumbuh sangat subur dan cepat berubah (hasil terlampir). Berbeda dengan kotoran kambing yang segar, bila untuk memupuk tanaman bisa menyebabkan tanaman tersebut mati karena mengandung biogas. Sedangkan kotoran gendon tidak mengandung biogas karena mereka makan sampah yang sudah diurai oleh bakteri fermentasi.

Dari perhitungan data pengamatan dapat dilihat bahwa pengomposan $1 \mathrm{~kg}$ sampah organik dengan stimulator EM4 da- 
lam waktu 1-3 minggu dapat menghasilkan pupuk bokashi rata-rata sebanyak $3,2 \mathrm{~kg}$. Sedangkan pengomposan $1 \mathrm{~kg}$ sampah organik dengan stimulator gendon dapat menghasilkan 3,3 kg pupuk gendoning hanya dalam waktu 4-7 hari. Dari perhitungan tersebut diketahui bahwa pupuk gendoning lebih cepat terbentuk dan lebih banyak kuantitasnya daripada pupuk bokashi.

\section{Pembahasan}

1. Parameter kompos

Menurut hasil penelitian Hastuti (2009) bahwa kematangan kompos yang dihasilkan diketahui dengan mengamati nilai rasio $\mathrm{C} / \mathrm{N}$. Rasio $\mathrm{C} / \mathrm{N}$ kompos dengan stimulator yang berbeda pada minggu ke 0, 3 dan 6 dan hasil terlihat pada tabel 2 .

Tabel2. Rasio C/N Kompos dengan Stimulator yang Berbeda.

\begin{tabular}{|c|c|c|c|c|}
\hline Minggu & \multicolumn{4}{|c|}{ Jenis Stimulator } \\
\hline & Kontrol & Cacing & EM $_{4}$ & Trichoderma \\
\hline 0 & 33,38 & & & \\
\hline 4 & 24,21 & 19,71 & 14,83 & 15,41 \\
\hline 6 & 21,05 & 18,36 & 9,76 & 11,24 \\
\hline
\end{tabular}

Penurunan rasio $\mathrm{C} / \mathrm{N}$ tersebut sejalan dengan kenaikan kadar $\mathrm{N}$ dan penurunan kadar $\mathrm{C}$. Selama dekomposisi protein terurai menjadi asam amino dengan bantuan mikroorganisme heterotrof. Kemudian melalui amonifikasi akan dibebaskan amonium yang selanjutnya dioksidasi menjadi nitrat (Alexander, 1977). Penurunan unsur karbon (C) disebabkan karena senyawa karbon organik digunakan sebagai sumber energi bagi mikroorganisme dan selanjutnya karbon tersebut hilang sebagai $\mathrm{CO}_{2}$. Penurunan rasio $\mathrm{C} / \mathrm{N}$ seiring dengan lama waktu pengomposan baik pada kontrol, , EM4 dan Gendon. Menurut Gaur (1980) kompos yang bisa diaplikasikan sebagai pupuk mempunyai rasio C/N maksimum 20. Dengan demikian kompos yang dihasilkan dari perlakuan stimulator sudah memenuhi syarat untuk dijadikan pupuk. 
Pada kompos dengan stimulator gendon ternyata rasio $\mathrm{C} / \mathrm{N}$ lebih tinggi dibandingkan dengan EM4. Hal ini disebabkan karena kandungan enzim selulase yang memecah C organik dalam bahan sampah paling rendah dibandingkan EM4 dan gendon. Tingginya enzim selulase pada gendon karena memang termasuk mikroorganisme selulotik, sedangkan EM4 merupakan kultur campuran mikroorganisme yang juga mengandung mikroorganisme selulotik.

Tingginya kandungan unsur hara pada perlakuan stimulator karena agen stimulator dapat meningkatkan proses peruraian unsur hara dalam bentuk ikatan komplek dengan sampah organik diubah menjadi bentuk mineral yang bisa diserap tumbuhan. Unsur hara pada kompos dengan stimulator cacing tanah menunjukkan hasil paling tinggi diduga karena cacing tanah mempunyai kemampuan makan yang tinggi, kemudian dimetabolisme dalam tubuh sehingga proses dekomposisinya lebih sempurna. Pada kompos stimulator EM4, unsur $\mathrm{N}$ dan $\mathrm{P}$ lebih rendah pada minggu ke 6 lebih rendah diduga karena bahan organik ini kematangannya lebih cepat dicapai sehingga unsur-unsur yang terbentuk hilang karena pencucian atau banyak digunakan untuk pertumbuhan mikroorganisme dalam kultur EM4.

2. Parameter tanah pada lahan kering dan kaku / wadas

Untuk mengetahui keberhasilan pengelolaan pertanian lahan kering dengan perlakuan pupuk organik dapat diketahui antara lain dengan menganalisis kandungan bahan organik tanah kandungan bahan organik kompos stimulator gendon dan EM4 paling tinggi kemudian diikuti gendon,kemudian EM4 yang paling rendah adalah kompos tanpa stimulator (kontrol). Tingginya bahan organik pada gendon disebabkan karena gendon mampu melakukan dekomposisi sampah organik secara sempurna. Dekomposisi tersebut dilakukan baik secara mekanik maupun secara enzimatis. Secara mekanis, sampah organik dicerna dalam saluran pencernaan dengan bantuan batuan-batuan kecil (kerikil) yang dimakan sehingga ukuran bahan sampah menjadi 
lebih kecil dan meningkatkan bidang permukaan bahan untuk pencernaan secara enzimatis. Sedangkan untuk EM4 pencernaan hanya dilakukan secara enzimatis sehingga kurang efektif dalam mendekomposisi sampah organik. Rendahnya bahan organik pada kontrol disebabkan karena mikroorganisme yang berperan dalam dekomposisi bukan mikroorganisme terpilih sehingga dekomposisi berjalan lambat. Kandungan bahan oganik setelah tanam menunjukkan penurunan disebabkan karena sebagian besar bahan organik sudah digunakan untuk proses pertumbuhan tanaman.

\section{Parameter Produksi}

Produksi labu air pada tanah urug wadas di lahan sekitar sekolah SMP Negeri I Kendal setelah diberi perlakuan jenis stimulator dan dosis pupuk organik yang berbeda menunjukkan hasil yang berbeda. Perbedaan tersebut disajikan pada Tabel 3.

Tabel 3 : Rata-Rata Jumlah daun,Panjang batang,jumlah bunga dan jumlah buah setelah perlakuan pupuk organik dengan jenis stimulator dan dosis yang berbeda.

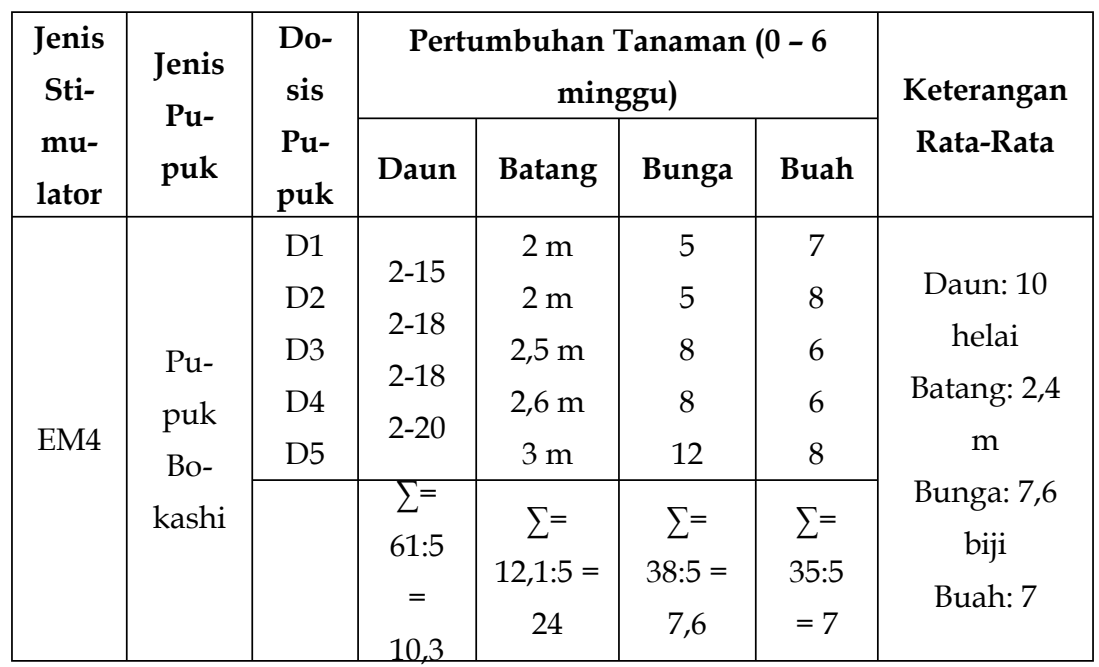




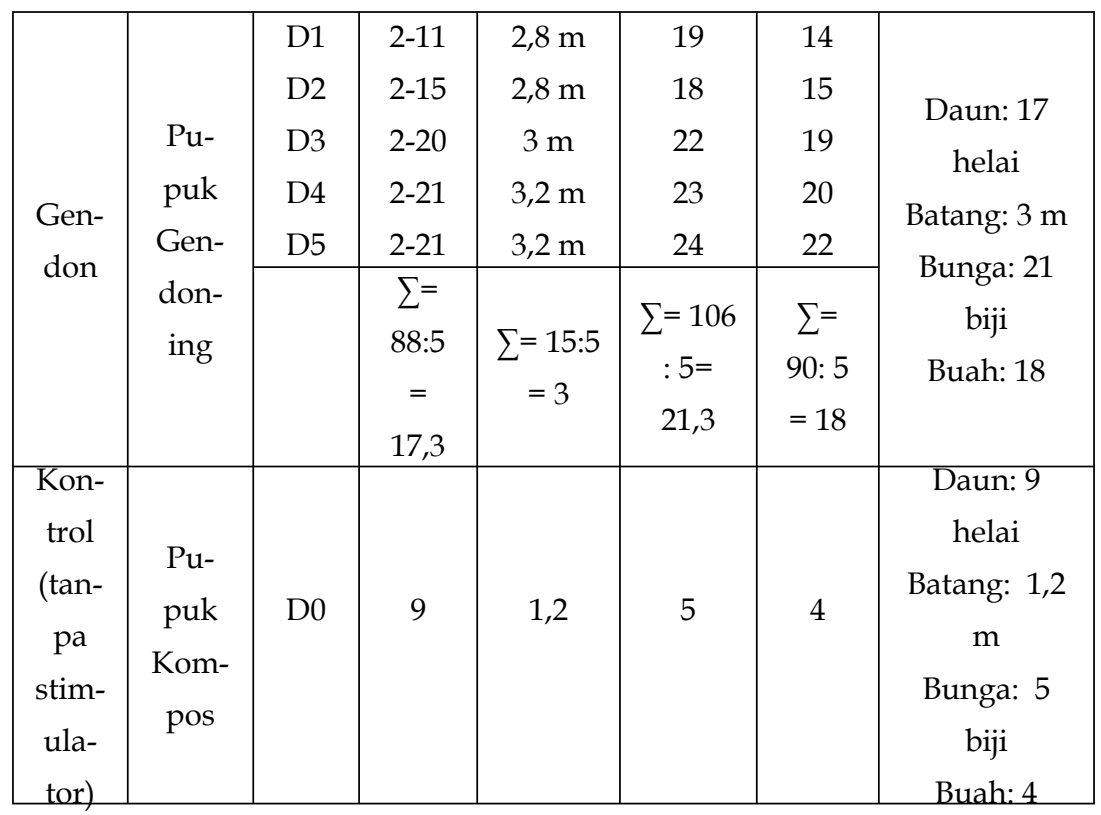

Tabel 3 menunjukkan bahwa perlakuan kompos dengan stimulator gendon dengan dosis ( $\mathrm{D} 0=0$ (kontrol), $\mathrm{D} 1=0,1 \mathrm{~kg}$, $\mathrm{D} 2=0,2 \mathrm{~kg}, \mathrm{D} 3=0,3 \mathrm{~kg}, \mathrm{D} 4=0,4 \mathrm{~kg}, \mathrm{D} 5=0,5 \mathrm{~kg}$ ) yang dilarutkan dalam satu liter air sudah dapat meningkatkan jumlah buah sebanyak 18 buah/pohon. Pada kompos stimulator dengan EM4 menghasilkan buah rata-rata hanya 7 buah/pohon saja. Dari situ diketahui bahwa hasil tanaman yang dipupuk menggunakan pupuk gendoning dapat berbuah 3 kali lebih banyak dari tanaman yang dipupuk dengan pupuk bokashi. Pada dosis yang seperti diatas baik kompos stimulator gendon dan EM4 semuanya sudah menunjukkan peningkatan jumlah buah jika dibandingkan dengan kontrol. Hasil peningkatan jumlah buah seiring dengan peningkatan dosis kompos. Hal ini disebabkan karena kandungan bahan organik dan unsur hara dengan dosis yang lebih tinggi semakin meningkatkan pertumbuhan vegetatif. Pertumbuhan vegetatif menentukan kecukupan cadangan makanan yang pada akhirnya meningkatkan produksi tanaman. 


\section{Kesimpulan}

Dari hasil dan pembahasan diatas dapat disimpulan sebagai berikut :

1. Bahwa gendon dapat dimanfaatkan untuk mesin pembuat pupuk gendoning. Pupuk gendon lebih unggul 3 kali efektif dari pupuk bokashi. Pemberian bahan stimulator gendon dan EM4 dapat memperpendek waktu pengomposan. Stimulator gendon dapat menghasilkan kompos dengan kualitas terbaik, sebagai hasil bioteknologi sederhana.

2. Kompos dengan stimulator gendon lebih efektif dari pada EM4 dapat meningkatkan produksi tanaman labu air pada lahan kering. Kompos berbahan stimulator gendon dosis 0,5 $\mathrm{kg} /$ pohon menghasilkan produksi labu air paling tinggi.

\section{Rekomendasi}

1. Atas temuan ini kami sarankan pihak-pihak terkait dapat memanfaatkan Larva Kumbang Kelapa yang dikenal dengan nama gendon dapat dimanfaatkan sebagai mesin biologi untuk membantu membuat pupuk gendoning.

2. Agar dilakukan penelitian lebih lanjut untuk meningkatkan pupuk gendoning yang lebih besar, sehingga dapat mengatasi kelangkaan pupuk. 


\section{DAFTAR PUSTAKA}

Dwidjoseputro, 1987, "Dasar-Dasar Mikrobiologi", cetakan 9, Djambatan, Malang, pp 71-72.

Hastuti, E.D., 2009, "Managemen Pertanian Lahan Kering Secara Berkelanjutan", Makalah disajikan dalam Seminar IATPI di Undip tanggal 06 Agustus 2009, hal.3.

Hermawan, A, 1996, "Pengembangan Rumput Vetiver dalam Sistem Usaha Tani Konservasi Lahan Kering", Balai Pengkajian Teknologi Pertanian, Ungaran.

Indriyani, Yopita H., 2002, Membuat Bahan Organik dengan Teknologi Efektif Mikroorganisme 4 (EM4), Cara Pembuatan dan Aplikasi. Jakarta : Kerja sama Indonesia Kyuseinature farming societies dan PT. Songgolangit Persada, 1995).

LAI, R, 1984, "Soil Erosion from Tropical Arable Land and Its Control", Adv. Agronomy. 37 : 183 -248

Prasetyo, T., Agus, H., Cahyati, S., 1996, "Peluang Pengembangan Usaha Tani di Lahan Kering Kritis melalui Penerapan Teknologi Spesifik Lokasi", Balai Pengkajian Tekonologi Pertanian, Ungaran.

Prastowo, K., Sibuea, L.H., Moersidi, S. dan E. Santoso, 1995, "Penambahan Pupuk untuk Mempercepat Pembuatan Kompos dari Bahan Sampah Pasar", Puslittanak Bogor.

Syam, M. Adi, W. Hermanto, Inu, G.I., Hans, A., Sabrawi, M., 
Efektivitas Pemanfaatan Pupuk Bokasi.....

1996, “Usaha Tanaman Pangan (Eds) Pusat Penelitian Pengembangan Tanaman Pangan", Badan Litbang Pertanian Bogor.

Simanjuntak, A.K. dan Waluyo, D., 1982, “Cacing Tanah Budidaya dan Pemanfaatannya. Penebar Swadaya", Jakarta.

Sudiharjo, A.M, 1996, "Perkiraan Luas Lahan Kritis Tingkat Tinjau di Propinsi Jawa Tengah berdasar Interpretasi dengan Metode Penilaian Alternatif dan Usaha Penyelamatannya", Makalah pada Seminar Hasil Penelitian Pola Usaha Tani Lahan Kering, Ungaran.

Oda, H., 1998, “Kumbang”, PT. Gramedia Jakarta. 